\title{
Transition: Trauma of the spiritual Renewal
}

Sanjin Sorel*

\begin{abstract}
Transition as a political and economic concept in literary culture is an empty signifier. The article detects frames of altered value relations and incidentally earned traumas through the paradigm of FAK-ian "type" realism. Both trauma and transition are spectacular and that is their only literary function.
\end{abstract}

Key words: transition, trauma, literature

* University of Rijeka, Department of Croatian Language and Literature ssorel@ffri.hr 
"Change is our mantra, monotony our constant" - a verse from the song "Take Care" by famous rock artist Damir Avdić, summarises all there is to say about transitology, memory, values, and ideologies: Human Reich. Trauma has a sublime voice in raw riffs and unforgiving verses. Polish sociologist Piotr Sztompka correctly detected the social causes of trauma in culture - it has to be swift/sudden, radical/encompassing, and exogenous/imposed from the outside, as it is mentally perceived as shocking (Sztompka $2000,452)$. Since it is accompanied by an inconsistency in culture and a lack of homogeneity and stability, it became polarised. Furthermore, multicultural societies repulsed by foreign cultures have a second source of trauma exemplified by concepts of ethnic collectivism (Sztompka 2000:454). Ethnic/national traumas from the past have returned at the beginning of the 1990s and have indicated, yet again, mechanisms of forced repetition. Trauma was merely a reflexive reaction to an unpleasant stimulus and, as well as the war, one concept forced itself in the guise of a mantra: transition.

Transition signifies an intermediary, a shift (Buden 2010, 121f). In economics and politics, it was usually defined as an encompassing shift from socialism to capitalism, that is to say, a transformation from the state economy to a, so-called, market economy and democracy. ${ }^{1}$ By common and banal assumption, anything that was not good has been transformed. Hence, it was obvious that socialism was a damaged good, and so we replaced it with a slogan: Croatian rifle on the Croatian shoulder, and Croatian wallet in the Croatian pocket. Twenty-five years later, the so-called post-socialism is described on web portals and newspapers, on TV, in magazines and books, by almost the same terms. It is clear (and expert literature is rife with apocalyptic intonations) that we are facing, yet again, a kind of error, and by all accounts the error is constitutionalised. John Locke was certainly an exception when at the very outset of his essential study, "An Essay Concerning Human Understanding", he acknowledged that although he was convinced that the theses are true, there is a considerable possibility all of them being false.

But what is an error? In Anićs Dictionary of the Croatian Language, it is defined as a lack. So, the next logical step is to ask ourselves - what is lacking? "Non-achievement at the heart of truth itself" (Žižek 2008, 49). And it is true that this paradox is constitutionalised, no matter the topic - whether it is subject, culture, poetics and politics, society and nature, and so on, we always reach the illusion, or:

The idea that one is able from the outset to account for error, to take it under consideration as error, and therefore to take one's distance from it, is precisely the supreme error of the existence of metalanguage, the illusion that, while taking part in illusion, one is somehow also able to observe the process from an 'objective' distance. [...] By avoiding identifying oneself

\footnotetext{
1 In literature, several fields of transition are covered: privatisation, trade and tariffs liberalisation, reform of the social and political system, and reform of enterprises. All of them are evaluated by the liberalisation index (WR), measurements showing a degree of the transitional progress.
} 
with error, we commit the supreme error and miss the truth, because the place of truth itself is only constituted through error. (Žižek 2008, 54)

Thus, no irony intended, it seems to me all that was wrong in socialism, as well as in our version of capitalism, is actually non-error. The same goes for the claim that for a quarter of the century "[...] culture [has been] understood as a fundament and bearer of the national identity" (Banović 2015, 161); and I would add, for ethnic clericalism as one of the generators of the spiritual development. Nevertheless, why is the discontent flourishing in the culture that holds constitutive and identity components - nation and religion - as infallible, moreover, as desired results? It would be completely wrong to understand Orwell's claim as wrong: "No nationalist ever thinks, talks, or writes about anything except the superiority of his own power unit” (Orwell, 2015). Because:

By 'nationalism' I mean first of all the habit of assuming that human beings can be classified like insects and that whole blocks of millions or tens of millions of people can be confidently labelled 'good' or 'bad'. But secondly - and this is much more important - I mean the habit of identifying oneself with a single nation or other unit, placing it beyond good and evil and recognising no other duty than that of advancing its interests. (Orwell, 2015)

But let us go back to the constitutionalised error we do not like at all (maybe because it is unethical)? Just like in the fairy tale "The Emperor's New Clothes", only children, who are the bravest of all, could see the obvious. The Emperor/Father as a representation of ideology, representation of error, is a mere panopticon. The concept of transition itself became an empty signifier, an autoreferential concept. In the context of a transitional object, it is only an illusion, in accord with Tertullian's proof for the content of faith in which one believes because it is absurd (credo quia absurdum).

It is obvious that in Croatian literature and culture, after a quarter of century, certain processes are clear. After the disintegration of Yugoslavia, the Other became an aversive concept. In general, two limiting values were cleaved - one is external, in relationship with other state entities, and to accomplish this, one needs to re-define identity, typically within national concepts (national: language, history, culture, food, the sky above the sea). The second, internal rift, occurs within the country, at least if we talk about Croatia, in the domicile culture, understood as a mythical place, with the traumatic year 1991 as its genesis. Recently, the bone of contention on internet portals was the question: "Where were you in 1991?" Abjection, as a fence, a safeguard and a limiting value, signifies the primers of one's own culture (Kristeva 1989, 8). One feature of the world is very interesting - every now and then it stops. We are talking about a caesura that, by biblical logic, knows the year in which the world began. Long duration presupposes a short memory, hence the definition for social identities repeatedly stumbles over a sticking point - tradition; and we do not want to know much of it, and so, for the most 
part, we imagine it and overwrite it, often forgetting documented sources. Transition largely ends in myth, or it simply signifies virtuality.

Actually, transition ended a long time ago. The epistemic cut, caused by the war, was, in essence, an illusion of the revolutionary break with previous social, cultural, economic and other paradigms. Therefore, transition as a concept has long since been an empty signifier, a mere platitude. But one of its aspects, the most important, is still active and is used to describe transition as a set of practices, from political to cultural, serving Western hegemony. We are talking about a performativity where an apparently innocent concept signifies a range of methods for subjugation, practices of colonisation. However, in trans-corporative reality, we have to keep appearances alive. For things to remain the same, everything must change, and in the case of the post-Yugoslav space, this conception certainly has mystical overtones because its executive power is always in delay; the revolution was a permanent process, so the transition should not end or even come close to its end: it should be a flowing revolution. Shift - from the past to the future - is an eschatological conception - the transition never ends because we know nothing about its beginning, and in the future, there is a hope that eventually the transition will be completed. Revolution is meaningless if it only presupposes a regime change. Concepts of socialist revolution and of Christian eschatology amazingly converge in the conception of the near future. Jacob Taubes saw the creative dimension of revolution in its ability to constitute new totalities in the world. Taubes, in a key statement, claims that "a nihilistic revolution does not pursue any goal [telos], but takes its aim from the movement itself and, in so doing, comes close to satanic practice” (Taubes 2009, 20). If we put aside devils and go back to our context, we could only see movement in the political-economic sphere, total nihilistic dynamics. It could not be clearer - discourse about the end of history is the master's speech, and the master is a master because we acknowledge his colonising status, since a slave is not independent. Hegel inserts the slave between the master and the thing, and the slave's dependence and his servitude are ruled by fear (Hegel 1986, 116-119). We already said that the transition primarily signifies a set of political-economic practices for governing a territory.

The only revolution in culture was the one we mentioned before, and now it is mainly dependent on the market. Generally, transition in culture would suppose a wide range of institutionalised, managerial, and evaluative strategies with the aim to bridge the gap between the socialist conception of culture and a capitalist market conception of culture (Zlatar 2010,117). This road leads from collectivist illusions to illusions of civil society, because we did not have collectivism in the past and we do not have a civil society today.

As regards culture, which culture are we talking of? All I can see are small and ghettoised spaces supporting an illusion of a culture. Publishing houses are devastated, and valuable books are printed only with grants by the Ministry of Culture of the Republic Croatia. Frankly speaking, for the price of two Euros, the price mentioned by the former Croatian politician and ex-keeper of the State seal, Ivan Milas, we subsidise Bulgarian literature, a literature that for the theoretician Stanko Lasić is closer to Croatian 
literature than Serbian literature, judging from his statement in the press. This story has its own geneses, and I am only interested in a genesis connected with memory: "The manipulation of collective memory makes no grand claims on the future. On the contrary, the historic memory serves as a monument to a people's historic suffering. Its focus is on the destructive side of the human species." (Furedi 2008, 120) It appears that we are forgetting a key document from the beginning of the cultural-spiritual transition, a collection of essays entitled "Spiritual Renewal of Croatia" published in 1992 and edited by Fra Ante Baković. The main thesis of the collection is very simple - human spirit has been devastated by socialism and we have to rebuild this spirit. How? We have to forget! History should have been erased in a way described by Baudrillard who noted that "one day we shall ask ourselves if Heidegger himself really existed" (Baudrillard 2001, 196). This is a radical standpoint implicating that modernist art practices, like Exat 51 and New Tendencies, the Zagreb Stylistic School and Praxis, Music Biennale Zagreb and Eurokaz, and many other institutions present in the European cultural space, did not really exist. But, a different miracle appeared and in the meanwhile has again disappeared; it materialised itself in downtown Zagreb and became the aesthetic paradigm for spiritual renewal in the 1990s - the museum The Miracle of Croatian Naive Art and the catalogue published in 1996 that revalorised a valuable phase of $20^{\text {th }}$ century Croatian painting. The road that leads from Sven Stilinović, Ivan Dodik Trokut, Tomislav Gotovac, Goran Trbuljak, and Edita Schubert in 1980s to the 1990s in which naive art became a visual representation of the ideology is very impressive. If trauma is a point of failure of symbolisation (Žižek 2002, 228), than it is obvious that Yugoslavia, as well as Croatia afterwards, have not succeeded to symbolically define themselves. In the latter case, symbolic identification was partial and incomplete by basic symbols of the statehood - the $\mathrm{flag}^{2}$ and the national anthem. ${ }^{3}$ Or maybe we have issues with design and vocal interpretation? And we are only talking about paradigms that conceal troubles with language, ideology, and culture in the broadest sense.

Again, we have to go back to the logic of beginning. Sasha Tsenkova (Tsenkova 2009) in her analysis of political, social, and economic transition in the post-socialism era made an obvious conclusion: there is an intensive downfall in all those concepts, coupled with a recommendation to continue with the consistent transition of changing the course from public to private, all in order to change the thesis - it was not transition that was problematic but the lack of it (Melich 2005, 117-139); a very cynical attitude indeed. In literature, its natural course was stopped, a continuity that Vojislav Mataga correctly described in the context of progression: modern - post-modern - trivial. Hence, the easiest way to describe the transition in literature is to present it in a context of changed paradigms, on the way from post-modernism to realism.

2 Disputes about the red/white first sqare in the coat of arms.

3 Milivoj Slaviček inserted the sea in the national anthem written by Antun Mihanović. 
Judging by criticism, transitology in literature signifies a renewal of realism. Noise in the understanding of the entire contemporary Croatian literature was produced by cultural studies with their propensity for psychoanalysis, theory of discourse, popular culture, hegemony, and so on, concerning questions of gender, identity, post-colonialism, consumption, etc. This contribution was welcomed because it pluralised the theoretical and academic environment, but an unwanted phenomenon of overinterpretation was also produced, with the analysis of this and that, as Meaghan Morris ironically observed about a tendency of cultural theoreticians to discern a subversive cultural potential in everything, in any banality (Meaghan 2015). But, a theory leaning on interpretative discourse was often unable to step back from what was offered from the so-called realistic fiction [stvarnosna proza]. This brand of fiction, although terminologically wrong but always present in the discourse of literary criticism, was mainly produced in the banal "the story is often linear, narration barren, the main motif connected with the immediate milieu, and in general decorated with a modicum of sex, alcohol, and drugs" (Bagić 2004, 121-122). I could not see any trace of subversive cultural potential in all that!

Transitology was embraced by the culturologist of culture Maša Kolanović and she defined the transition in an ideological context, ranging from socialism to transition, while she was aware that the concept is vague (Kolanović 2011, 27). Although literature as a socialist and capitalist cultural form was interpreted in many ways after the year 1991, something remained the same - literary genres. In the context of poetics, "an urban motif, a strong affiliation with characters from the urban margin... colloquial (even jargon) language, hard erotica verging on pornography, and a rather strong fabular structure..." (Visković 2006: 29), are practically synonyms for the blue jeans fiction. In the context of genre, we have a regression, and something more important as well a sweet decadence of the post-modernism has incorporated modernist worldviews that became traditional in the conception of a miracle of Croatian naive art. As Latour said: "Real as Nature, narrated as Discourse, collective as Society, existential as Being: such are the quasi-objects that the moderns have caused to proliferate. As such it behooves us to pursue them, while we simply become once more what we have never ceased to be: amoderns." (Latour 2004, 92)

In order to sketch the narrative transition in Croatia, I will use the example of the socalled FAK. The group of writers labelled with this tag had the biggest media visibility in the past twenty-five years and their poetic and aesthetic conceptions were dominant not only in Croatian literature.

A certain non-modernity of members of the FAK group was systemic, and they were deconstructed even by their name. It began as a Festival of Alternative Literature and ended as Festival of Literature. During 1980s, the term alternative indicated various practices aimed to subvert culture from the margins, but the term with emphatic A occupied a position to claim values of what was deconstructed. The FAK was, in a way, similar to punk rock working in the frame of rock music aiming to announce the death of rock but became a fashion in the 1990s. In the context of the FAK, it seems that its 
members were neither alternative nor the A class. The FAK did not contribute anything to the Croatian literature in poetic, stylistic, or value terms that had not already been there before the 1990s. Moreover, the writings of this group are full of stereotypes and commonplaces.

The FAK dissolved at the moment when writers Arijana Čulina and Vedrana Rudan had sold more copies of their books than all members of the group together. Furthermore, Vedrana Rudan correctly reinterpreted a scandal in Croatian society, politics, and culture, when she simply stated: The emperor has no clothes. As members of the FAK group were enjoying writing pornography for Libido.hr like teenagers, Rudan recognised it as a needle in a haystack of Croatian polite gestures. In other words, she openly problematised all traumatic themes in Croatian politics and culture, as well as those who were responsible for these traumas, and subsequently deconstructed a false opposition, an illusion about the FAK as alternative.

Croatian fiction in the 1980s often described the disappearance of classical themes, displaced by various types of experiments, conceptuality, meta- and inter-textuality, and irony. This development had its own inherent reasons and logic. During the 1990s, the motto "activate our differences" was displaced by the statement of Robert Perišic in 2011: "Writers were led down the garden path believing they have to earn their living on the market." ${ }^{4}$ Holding ${ }^{5}$ literature was in part a reaction to the incomprehensible discourse of some postmodern literature for the readership. Milan Galović pertinently described a genesis of kitsch art: "It seems that this kind of art emerged particularly when artists became more and more incomprehensible to the general public. Literary works were produced full of compilations and intelligible details but the whole was lost" (Galović 2011, 64).

Tomislav Zagoda correctly described a commercial, fictional, and intellectual transitology in the case of Baretić's novel The Eighth Commissioner. With the distance towards mere observation about banalities in literature, he simultaneously detected banalities in literary criticism. I could hardly add anything to this quote:

Therefore, the main components of a model for so-called ordinary readers in times of transition are: proclivity to undemanding reading, appetite for trivial literature, modest competence and knowledge, decoding of the meaning of literature by the reference to social reality, absolute dominance of synchronic over diachronic and material substance over spiritual, and usage of literature as therapeutic method with the aim to escape from the disappointing space of social reality. But, apparently the most provocative question about the interpretative community in times of transition is

\footnotetext{
4 http://www.novilist.hr/Kultura/Knjizevnost/Robert-Perisic-Pisci-su-jedini-popusili-pricu-da-morajuzivjeti-samo-od-trzista, October 14, 2015.

${ }^{5}$ Zagrebački Holding d.o.o. - a company owned by the City of Zagreb providing utility, traffic, energy and other services.
} 
linked with reception of The Eighth Commissioner by competent readers, critics, and literary theoreticians, and evaluators. Hence, I believe that in the interpretative community in times of transition two types of readers merged, which points to an essential erasure of boundaries between high and low culture, and to the absolute domination of synchronic codes. Eventually, the academic community and a "group" around Perišić were sitting together at a literary bar sipping the (non)sense of refreshing, "readable", and entertaining literature. (Zagoda 2009)

When literature is clear and easy to understand, its accessibility and marketing logic aestheticises the market and eventually de-aestheticises the literature. In reality, inherited structures used for the non-problematisation of a genre, chiefly the novel, are accepted and, as Rastko Močnik noted, a literary aesthetics that partially legitimises the fascistisation of a society ${ }^{6}$ (Močnik 1998-99, 89-90) is coming from the spoken ideology of the written literature. What does this mean in the Croatian context of the FAK? The most important paradox shows that, contrary to clear ideological and anti-fascist standpoints in the society, the literature is exposed to latent, apparently unimportant processes that undermine resistance to the slow fascistisation of the society. A minor literary device defining the base of realism testifies to this in the case of, for example, Perišić, Tomić, Pavičić, Baretić, etc., and the device is dialogue. Dialogue is, in fact, a transcription of speech, a written translation of oral discourse. Trauma gained its voice through the speech of literary characters. Orality/dialogue is a basic literary device for this literary group and probably a fundamental narrative stylisation; even if the group declaratively/phenotypically clearly distanced itself from the xenophobia on the genotypical level, we could notice an incursion of the oral culture that produced the same xenophobia. However, these themes are closer to those analysed by Georges Deveraux in his book Basic Problems of Ethnopsychiatry.

Because trauma is bounded with fixations and language is a site that supersedes the real by the systems of symbolisation referring to reality produced in the process of symbolisation itself, we have eventually forgotten its residue. What kinds of fixations are present in Croatian society? Very simply, as we said it before - national identity, and implicitly the relationship toward the Other. As Croatian culture and politics were trying unsuccessfully to construct themselves symbolically, and psychoanalysis taught us that symbolic overwrites the real (Fink 2009, 31), the suppressed sites are coming back in unbearable forms. For example, the magazine Feral Tribune used to publish many

\footnotetext{
6 "Spontaneous ideological reactions of mass groups, those who are the most afflicted by 'transition' to capitalism on the periphery, are expressed with popular and trivial schemes from the dominant culture. Mass existence of the dominant culture more and more becomes a quotidian fascism, with thousands of forms no one has yet described. Contrary to organised fascism encompassing a party, a fraction or a leading group, against which one could fight with a classic methodology, a quotidian fascism is protean, unexpected, often naive and 'innocent', and so to speak, coming straight from the heart. And, naturally, this is a reliable indication of the hegemony." (Močnik 1998-99, 89-90)
} 
articles about this issue. Ante Lešaja, in his book Uništavanje Knjiga u Hrvatskoj 1990-ih (The Destruction of Books in Croatia During the 1990s), documented this practice and Milan Šarac, in his review of the book, said: "The greatest irony of all book burnings is that all of them would finally end up in a book. Books always strike back." The destruction of memory committed by the culture of forgetting is a reflection of the failed relationship with its own identity.

The situation is not any better in the literary scene or in literary criticism. For example, Velimir Visković dubbed the above-mentioned writers as neo-realists or new realists, in an attempt, similarly to Jagna Pogačnik, to detect and describe this neoand new with a subject-thematic analysis, but those prefixes could not blur an obvious reality of the poetics. What should be written is a book describing the development of Croatian realism from $19^{\text {th }}$ century until today, from the beginnings of this poetic to its deconstruction. FAK's version of realism was divested of its grounding in literature symbolisation, allegory, and connotation. We are facing the illusion of literature and the totalisation of the present, of today. As Baudrillard deprived the denotation of its role, and subsequently erased the real reducing it to simulation, the FAK group conceived the symbolic as a loss of the sign, but not of its value. If reality is simulated and constructed, what kind of referent could the realism of FAK account for, then? With the repetition of schemes developed in the blue jeans fiction, they are accepting them in the same, post-apocalyptic, and wartime context, and by that they accentuate the impotence of their own tautological poetics. The literary poetics of the FAK is a surplus. Since value surplus always designates a gain in the Other, the subject is caught in the constant process of producing surplus pleasure for the Other. Or, I would say - in the FAK-type of literary realism, there is too much realism, hence the abundance of neurotics in its novels and short stories. But that is another story.

\section{References}

Bagić, K. 2004. Treba li Pisati Kako Dobri Pisci Pišu. Zagreb: Disput.

Banović, S. "Nedostatak Strategije Razvoja Nacionalnih Kazališnih Kuća i Hrvatsku Kulturni Identitet.” Accessed: 24 June, 2018. http://tripalo.hr/knjige/NacIdent/banovic.pdf.

Baudrillard, J. 2001. Simulacija i Zbilja. Zagreb: Naklada Jesenski i Turk/Hrvatsko Sociološko Društvo.

Buden, B 2010. “Kada su Slobodi Bila Potrebna Deca.” Sarajevske Sveske 27-28.

Fink, B. 2009. Lakanovski Subjekt, Izmedu Jezika i Jouissance. Zagreb: Kruzak.

Furedi, F. 2008. Politika Straha - S Onu Stranu Ljevice i Desnice. Zagreb: Antibarbarus.

Galović, M. 2011. Doba Estetike - Estetika Lijepog - Problemi s Ljepotom: Od Totalitarne Prijetnje do Fascinacije Ljepotom "Digitalnog Privida”. Zagreb: Antibarbarus/HDP.

Hegel, G. V. F. 1986. Fenomenologija Duha. Beograd: BIGZ.

Kolanović, M. 2011. Udarnik! Buntovnik?, Potrošač... Popularna Kultura i Hrvatski Roman od Socijalizma do Tranzicije. Zagreb: Naklada Ljevak. 
Kristeva, J. 1989. Moći Užasa. Zagreb: Naprijed.

Latour, B. 2004. Nikada Nismo Bili Moderni, Ogled iz Simetrične Antropologije. Zagreb: Arkzin/Aiir. Mandić, Davor. 2011. "Robert Perišić: Pisci su Jedini Popušili Priču da Moraju Živjeti Samo od Tržišta (Intervju).” Accessed: June 24, 2018. http://www.novilist.hr/Kultura/Knjizevnost/Ro bert-Perisic-Pisci-su-jedini-popusili-pricu-da-moraju-zivjeti-samo-od-trzista.

Melich, S. Jiri. 2005. "Breaking the Postcommunist Liminality: The Transformation Process in Eastern Europe.” Demokratizatsiya 1: 117-139.

Močnik, R. 1998/99. Koliko Fašizma? Zagreb: Arkzin.

Morris, M. 1991. Banality in Cultural Studies. Accessed: June 24, 2018. http://www.haussite.net/ haus.O/SCRIPT/txt1999/11/Morrise.HTML.

Orwell, George, Crtice o Nacionalizmu. Accessed: June 24, 2018. http://pescanik.net/crtice-onacionalizmu/.

Piotr S. 2000. "Cultural Trauma - The Other Face of Social Change." European Journal of Social Theory 3(4): 449-466.

Taubes, J. 2009. Zapadna Eshatologija. Zagreb: Antibarbarus.

Tsenkova, S. 2009. Housing Policy Reforms in Post Socialist Europe: Lost in Transition. Heidelberg: Physica.

Viskovć, V. 2006. U Sjeni FAK-a. Zagreb: VBZ.

Zagoda, T. 2009. "Model Razočaranog Čitatelja (Pragmatička Analiza Baretićeva Romana Osmi Povjerenik).” Kolo, No. 5. Accssed June 24, 2018. http://www.matica.hr/kolo/312/Model

Zlatar, A. 2010. "KULTURA I TRANZICIJA: Od Strategije Kulturnog Razvitka do Menadžmenta u Kulturi." Sarajerske Sveske 27-28.

Žižek, S. 2008. Ispitivanje Realnog. Novi Sad: Akademska Knjiga.

Žižek, S. 2002. Sublimni Objekt Ideologije. Zagreb: Arkzin. 